\title{
A large-scale assessment of European rabbit damage to agriculture in Spain
}

\author{
Miguel Delibes-Mateos, ${ }^{\mathrm{a}, \mathrm{b}^{*}} \odot$ Miguel Ángel Farfán, $^{\mathrm{c}, \mathrm{d}}$ Carlos Rouco, ${ }^{\mathrm{e}}$ \\ Jesús Olivero, ${ }^{c}$ Ana Luz Márquez, ${ }^{c}$ John E Fa, ${ }^{f}$ Juan Mario Vargasc \\ and Rafael Villafuerte ${ }^{b}$
}

\begin{abstract}
BACKGROUND: Numerous small and medium-sized mammal pests cause widespread and economically significant damage to crops all over the globe. However, most research on pest species has focused on accounts of the level of damage. There are fewer studies concentrating on the description of crop damage caused by pests at large geographical scales, or on analysis of the ecological and anthropogenic factors correlated with these observed patterns. We investigated the relationship between agricultural damage by the European rabbit (Oryctolagus cuniculus) and environmental and anthropogenic variables throughout Spain.
\end{abstract}

RESULTS: Rabbit damage was mainly concentrated within the central-southern regions of Spain. We found that rabbit damage increased significantly between the early 2000s and 2013. Greater losses were typical of those areas where farming dominated and natural vegetation was scarce, where main railways and highways were present, and where environmental conditions were generally favourable for rabbit populations to proliferate.

CONCLUSION: From our analysis, we suggest that roads and railway lines act as potential corridors along which rabbits can spread. The recent increase in Spain of such infrastructure may explain the rise in rabbit damage reported in this study. Our approach is valuable as a method for assessing drivers of wildlife pest damage at large spatial scales, and can be used to propose methods to reduce human - wildlife conflict.

๑) 2017 Society of Chemical Industry

Supporting information may be found in the online version of this article.

Keywords: Google search; human - wildlife conflict; landscape change; Oryctolagus cuniculus; pest species; small mammals

\section{INTRODUCTION}

Negative impacts of wildlife on humans or their resources have occurred throughout prehistory and recorded history. Consequences of human - wildlife conflict can be both direct, including disease, injury and death from encounters with dangerous animals, and indirect, such as loss of crops and livestock and damaged infrastructure. Measures for preventing or reducing human - wildlife conflict are increasingly being developed. ${ }^{1}$ Successful conflict resolution plans are often the result of the assimilation of proven methods of control or deterrence and their clear adaptation to the nature of the problem at hand. ${ }^{2}$ The latter requires an accurate assessment of the human - wildlife conflict situation investigated, and a clear understanding of the efficacy, cost-effectiveness and social acceptability of the methods to be applied.

Although human - animal conflict involving large mammals is often highlighted in the media, human livelihoods are arguably much more impacted by small and medium-sized mammals.,4 These species often cause substantial damage to pastures as well as ground and tree crops through grazing or browsing. For example, outbreaks of rodents in apple-growing areas in Germany can cause up to $€ 25$ million per year of damage. ${ }^{4}$ Close grazing by large numbers of the European rabbit (Oryctolagus cuniculus) can weaken or kill even persistent leafy crops, and scratching and burrowing can degrade pasture still further by encouraging the establishment of weeds. ${ }^{5}$ In the UK, rabbit damage was recorded

\footnotetext{
* Correspondence to: M Delibes-Mateos, Departamento de Biología Vegetal y Ecología, Facultad de Biología, Universidad de Sevilla, Apartado 1095, 41080, Sevilla, Spain.E-mail:mdelibesmateos@gmail.com

a Departamento de Biología Vegetal y Ecología, Facultad de Biología, Universidad de Sevilla, Sevilla, Spain

b Instituto de Estudios Sociales Avanzados (CSIC), Córdoba, Spain

c Departamento de Biología Animal, Facultad de Ciencias, Universidad de Málaga, Málaga, Spain

d Biogea Consultores, Málaga, Spain

e Departamento de Zoología, Campus de Rabanales, Universidad de Córdoba, Córdoba, Spain

$f$ Division of Biology and Conservation Ecology, School of Science and the Environment, Manchester Metropolitan University, Manchester, UK
} 
as being $€ 115-150$ million in $1986,{ }^{6}$ and around $€ 130$ million per year in Australia. ${ }^{7}$

Country-wide assessments of the damage caused by rabbits in the UK and Australia ${ }^{8,9}$ and by coypu (Myocastor coypus) in Italy ${ }^{10}$ have been undertaken. However, analyses of the spatial (where damage happens) and temporal (when damage occurs) factors determining the crop damage inflicted by a particular pest species have been largely missing from large-scale assessments. Such approaches allow for the application of understanding of what variables may correlate with a species' propensity to cause damage and thus can permit managers to devise more effective measures of control, especially as what may be successful at a smaller demonstration scale can fail when applied at the broader landscape level. ${ }^{11}$

Pest outbreaks can be linked to specific environmental conditions. In the case of the Douglas-fir tussock moth (Orgyia pseudotsugata), eruptions correlated primarily with forest type and climate. $^{12}$ However, for some species, particularly insect pests, transport infrastructure (roads and railway lines) can also permit their dispersal and establishment. ${ }^{13}$ There are few studies on the role of roads and railways as potential corridors along which pest species may disperse. An exception is a study of the brown marmorated stink bug (Halyomorpha halys) in the USA, which showed that urban development and railroads facilitated the species' spread. ${ }^{14}$ Given the ubiquity of transport infrastructure in many parts of the world, it is likely that pest species will reach remote areas as they establish themselves along roads or railway lines where they can become abundant, and from which they can proliferate. ${ }^{15}$

Assessing crop damage caused by indigenous small mammal pests, as well as increasing our understanding of what determines this, is important when the species in question also plays a key role in a native ecosystem. This is the case for the European rabbit in the Iberian Peninsula, its native range. ${ }^{16}$ The control of the rabbit here needs to be effected in such a way that does not cause its unrestrained decline or extinction; this could produce cascading effects in the ecosystem. ${ }^{16}$ Rabbits in Iberian Mediterranean ecosystems act as a multifunctional keystone species, not only because they are prey for over 30 predators, but also because of their role as an ecosystem engineer. ${ }^{17}$ By contrast, rabbits cause substantial damage to agriculture in Spain and Portugal, ${ }^{18-20}$ and are regarded as a severe pest species in some regions. Moreover, rabbits are one of the most important small-game species, hunted in their millions in the two Iberian countries. These multiple roles often lead to frequent conflicts between farmers, hunters and conservationists regarding how to manage the species. ${ }^{18}$

Knowing where and when rabbit damage occurs in Spain and which factors may drive it can help mitigate conflicts between the various stakeholders. In this study, we first describe rabbit damage throughout Spain, until now unrecorded, by: (1) documenting areas (i.e. municipalities) where rabbit damage has been reported to occur; (2) recording which crops are affected; and (3) evaluating the temporal evolution of rabbit damage in the country. Across multiple sites, we then assess the probability of occurrence of crop damage caused by rabbits, and its relationship with local conditions and environmental factors, such as land use, natural vegetation or infrastructure. To do this, we employ large-scale databases of environmental and biotic variables, and use spatial modelling. ${ }^{21}$ Our results are used to determine which areas are more prone to rabbit damage and assess which factors are correlated with this.

\section{MATERIALS AND METHODS}

\subsection{Study area}

Peninsular Spain covers $493518 \mathrm{~km}^{2}$ (nearly $85 \%$ of the Iberian Peninsula). The country is divided into 8125 administrative municipalities (http://www.ine.es), the territorial units used in the current analyses. Climate varies widely throughout Spain, with precipitation decreasing eastwards and southwards, and temperature increasing southwards. ${ }^{22}$ Mountains border the northern and Mediterranean coasts (maximum altitude $3478 \mathrm{~m}$ ) but there are also east-west facing ranges in the centre of the Peninsula.

The natural vegetation in the mountains is pine and oak forests and scrubland, but lowlands are mostly dominated by herbaceous crops and river terraces, and hill slopes by woody crops such as olive. According to the 2010 European Union Farm Structure Survey (FSS), the area under agriculture in Spain was $47 \%$ of the whole territory and involved around $9.8 \%$ of the economically active population of the country (http://ec.europa.eu/ eurostat/web/agriculture/farm-structure). Arable land dominates over woody crops $\left(\sim 12 \times 10^{6}\right.$ ha versus $\sim 5 \times 10^{6}$ ha, respectively). Cereal crops and olive trees represent just over $50 \%$ of arable land and woody crops, respectively. Fodder crops cover an important area of arable land, while fruit trees and vineyards are common woody crops. ${ }^{23}$

\subsection{Temporal and spatial characterisation of damage caused by rabbits}

We used the Google search engine (www.google.es) and the search terms "pest" and "rabbit" (in Spanish: "plaga" and "conejo", respectively) to identify websites containing information on areas affected by European rabbits in Spain. ${ }^{24}$ We selected this word combination based on a previous study which showed that this permutation, but also "rabbit" and "damage", worked better than "rabbit" and "crop", and "rabbit" and "overpopulation". ${ }^{25}$ The first 600 consecutive sites resulting from our Google search were visited and their content evaluated by M. Delibes-Mateos. ${ }^{24}$ Searches were performed between 18 May and 11 June 2015. Only websites unequivocally containing information on damage caused by the European rabbit in Spain were considered valid. These sites mostly included media reports on rabbit damage, discussion forums on hunters' and farmers' websites, and blogs. Websites that bore no relation to rabbit damage in Spain were discarded. Among those ruled out for analyses were websites dealing with pest rabbits in regions where the species is an invasive alien or advertisements for pet rabbits. We gathered information on the type of agricultural crop damaged by rabbits. As one of our main goals was to determine areas where rabbit damage occurred, we also documented those municipalities where such damage was reported. To assess the temporal evolution of the annual online information on rabbit damage in Spain, we recorded the year that each website was uploaded. Because internet usage has substantially increased in recent years, thus affecting the availability of media reports on rabbit damage, we used the date function available in Google Advanced Search to conduct a search of the target keywords filtering by year for the period 2004-2014. The first 100 sites yielded by each search (i.e. for each specific year) were visited and those that were valid were selected to calculate a standardised index of available information on rabbit damage in each year; i.e. for each year, the number of valid websites/100 websites visited. The temporal evolution of such an index was compared with the evolution of the reports on rabbit damage obtained from the general search (see above). 


\subsection{Predictive model}

To model the potential distribution of European rabbit damage throughout mainland Spain, we used the favourability function. ${ }^{26}$ The favourability function assesses the extent to which environmental conditions change the probability of occurrence of an organism with respect to its overall prevalence in the study area. ${ }^{27}$ Thus, compared to logistic regression, by using the favourability function we cancel out uneven proportions of presences and absences in the modelled data. Here, we use this approach to model the relationship between European rabbit damage and environmental variables.

Firstly, a model of environmental favourability for the presence of the European rabbit in each Universal Transverse Mercator (UTM) $10 \times 10 \mathrm{~km}$ square of mainland Spain was constructed using the distribution map available in the Atlas of Terrestrial Spanish Mammals and Red Book. ${ }^{28}$ We considered 35 predictor variables (Table S1). The ecological factors that could explain the environmental favourability of the European rabbit were based on climate and topography. Alongside these, we included descriptors of human land use and human activity to assess potential anthropogenic impacts.

Overall, our model of European rabbit damage included 136 predictor variables (Table S2): the favourability model for the presence of European rabbits, as a variable representative of the environmental conditions that determine the presence of the species; 79 ecosystem type descriptors based on natural vegetation structure, and 56 indicators of anthropogenic activity in terms of transport infrastructure (i.e. main railways and highways), agriculture and livestock. Spatial analyses to calculate the presence of transport infrastructure were performed using ArcGIS 10.0 (ESRI, Redlands, (A, USA).

We excluded nonlinear and interaction effects from the model to keep its mathematical formulation as simple as possible for explanatory purposes. To account for Type I errors caused by the large number of variables considered, we controlled the false discovery rate (FDR). ${ }^{29}$ Thus, using the presence/absence of European rabbit damage as the dependent variable, we ran a logistic regression on each of the 136 predictor variables, and only significant $(P<0.05)$ variables under an FDR of $q<0.05$ were accepted as part of a multivariate environmental model. Multicollinearity was also minimised by excluding variables that were correlated with Spearman $r>0.8$. Only then did we implement the favourability model using the following equation ${ }^{26,27}$ :

$$
F=[P /(1-P)] /\{(n 1 / n 0)+[P /(1-P)]\}
$$

where $F$ is the favourability value in each municipality; $n 1$ and $n 0$ are the number of municipalities with and without damage reported in websites, respectively; and $P$ is the probability of rabbit damage presence in each municipality. $P$ was calculated with a multiple logistic regression, using the presence and absence of damage in each municipality according to the analysed websites as the dependent variable. A forward stepwise procedure was performed to avoid the inclusion of redundant variables in a model. The parameters in the models were fitted by iteratively maximising the log-likelihood (using IBM statistics 22, International Business Machines, New York, USA).

\subsection{Explanatory analysis of variables in the model}

We employed a variation partitioning procedure to measure the relative participation of the four main factors described in Table S2 (favourability for the presence of European rabbit, transport infrastructure, natural vegetation and land uses) in the model explanation of favourability for damage occurrence. ${ }^{30}$ In this way, we specified how much of the variation in favourability was accounted for by the pure effect of each factor (i.e. variation that is not affected by covariation with another factor), and what proportion was clearly attributable to more than one factor (i.e. shared effect).

The significance of the influence of all variables in the model was assessed using the univariate Wald test statistic. ${ }^{31}$ Stepwise methods select variables acting on a larger scale in the first steps, and at subsequent steps only add variables that are significantly related to the residuals not accounted for by previously incorporated variables. ${ }^{32}$ The regional relevance of every variable was, thus, analysed using two approaches. Firstly, we measured the correlation (Spearman $R$ ) of each variable with the favourability output, and compared the sign of $R$ (which indicates global relationship within the study area) with the sign of the variable coefficient in the model equation (which indicates the sign of the variable contribution to explaining favourability). Secondly, we visualised the regional contribution of each variable to the model by mapping the difference between favourability values obtained in successive steps, along the stepwise variable selection.

\section{RESULTS}

\subsection{Temporal and spatial characterisation of damage caused by rabbits}

The general Google search yielded a total of 306 unique, valid websites containing information on damage caused by European rabbits in Spain. The first cases of rabbit damage were reported in 2004. There were few cases during 2004-2006, but cases increased sharply thereafter until 2013, after which there was a sharp decline (Fig. 1). In 2014, we recorded the highest number of websites containing information on rabbit damage, reaching levels higher than in 2012. There was a strong significant correlation $(R=0.971 ; P<0.001)$ between the number of websites containing information on rabbit damage and year when we standardised our results using the Google search by date option. Nearly all analysed websites reported crop damage caused by rabbits $(95.7 \%$; $n=301)$, with only a few documenting damage to infrastructure around railways or highways $(10.3 \% ; n=301)$, or human properties such as gardens or parks $(9.6 \% ; n=301)$. Most rabbit damage was reported for vineyards and cereal crops $(66.1 \%$ and $53.3 \%$, respectively; $n=180$ ), although it was also relatively frequent in olive groves and fruit orchards ( $28.3 \%$ and $21.7 \%$, respectively; $n=180$ ). Green vegetables and other crops were less frequently mentioned on the websites ( $15.0 \%$ and $9.4 \%$, respectively; $n=180$ ). Rabbit damage was reported in 437 (5.5\%) municipalities across mainland Spain. These were mostly found in: (1) Guadalquivir and Ebro valleys in southern and northeastern Spain, respectively; (2) Castilla-La Mancha and Castilla y León plateaus in central Spain; and (3) the coastal eastern regions, particularly the Comunidad Valenciana region (Fig. 2).

\subsection{Modelling favourability for European rabbit damage}

The favourability model for the presence of European rabbit damage included 18 different variables related to transport infrastructure, land use, natural vegetation and environmental variables (Table 1). The model showed that municipalities favouring the presence of European rabbit damage tended to be found near each other (Fig. 3), located mainly along the Guadalquivir and 


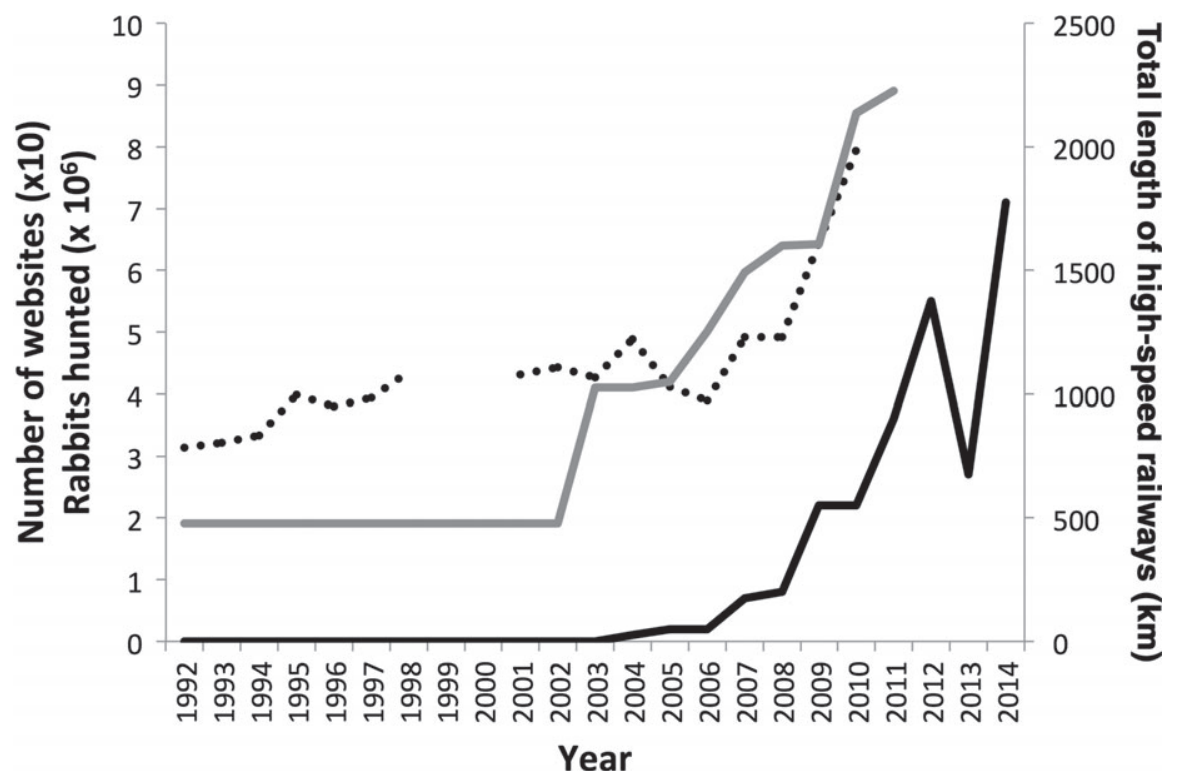

Figure 1. Evolution of the number of websites containing information about European rabbit damage according to a Google search (solid black line), the total length $(\mathrm{km})$ of high-speed railway in Spain (grey line; source: http://www.spanishrailwaysnews.com), and the number (in millions) of rabbits hunted in Spain (dotted line; source: http://www.magrama.gob.es and Delibes-Mateos et al. ${ }^{46}$ ).

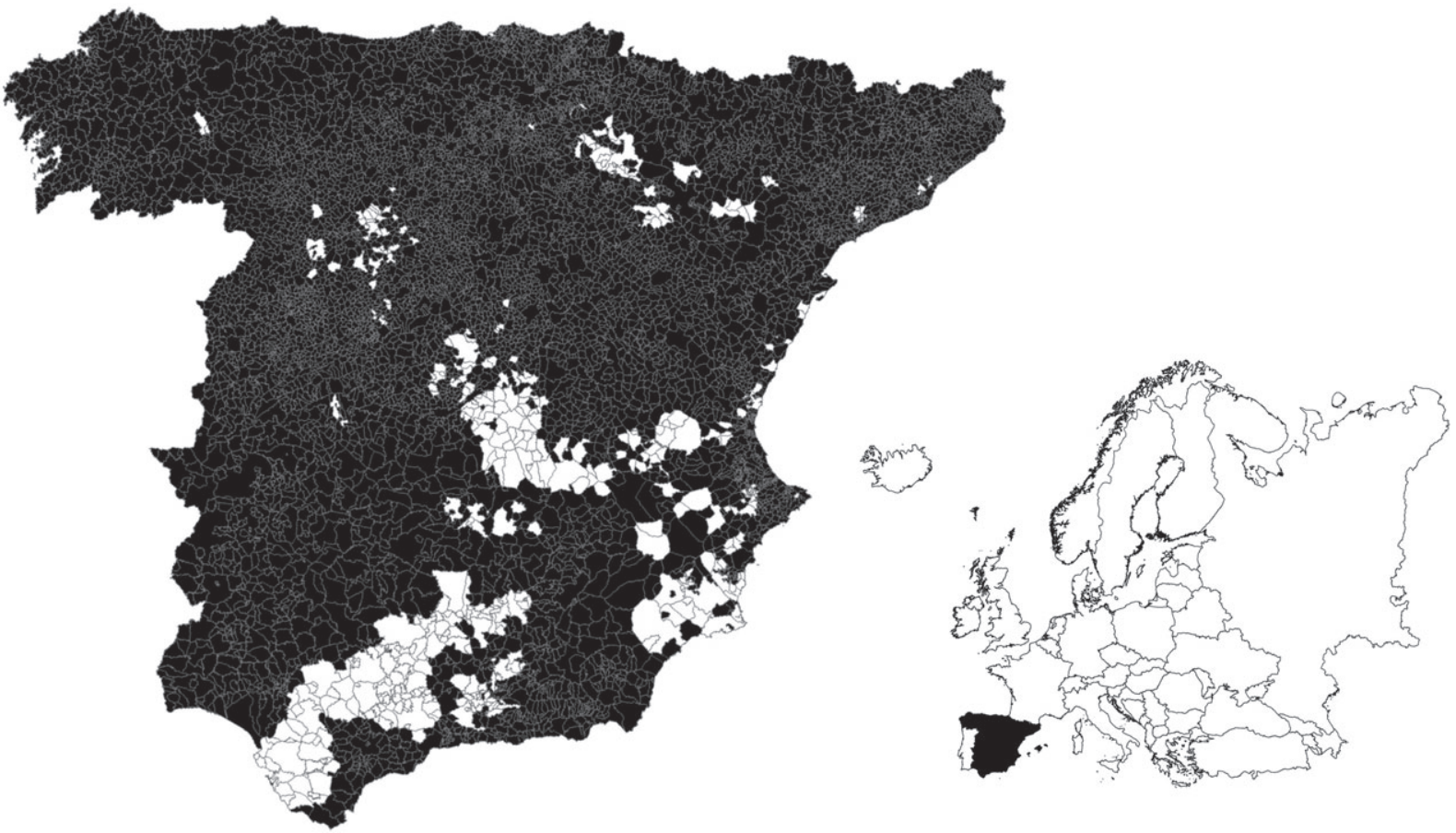

Figure 2. Municipalities reporting European rabbit damage within the study area (in white) according to the analysed websites (see text for details).

Ebro valleys, several areas of the Guadiana valley, northern and southern plateaus and some coastal areas of southeastern peninsular Spain.

Variables with the highest explanatory power within the model (Wald statistic $>25$ ) were primarily transport infrastructure and land use descriptors (Table 1). Humanised habitats, such as croplands and infrastructure, and environmentally favourable areas for the presence of European rabbits were positively related to damage. In contrast, natural vegetation was negatively associated with rabbit damage. More specifically, highways and main railways, dry and irrigated olive crops, and dry and irrigated vineyards positively correlated with the occurrence of European rabbit damage, i.e. they showed identical signs within the model equation and in the variable correlations with the model, and their entry into the model produced an increase in favourability (Fig. 4). In contrast, forests (especially mature oak forests), scrublands and pastures represented environmental constraints to the occurrence of European rabbit damage, i.e. both signs within the model equation and variable correlations within the model were negative, and their entry into the model produced a decrease in favourability (Fig. 4).

The greater proportion of the spatial variation in favourability was explained by habitat descriptors, represented by natural 
Table 1. Descriptor variables of the environmentally favourable areas for European rabbit damage according to the favourability model

\begin{tabular}{|c|c|c|c|c|c|}
\hline Variable & Step & W & CfS & $\mathrm{CrS}$ & AGI \\
\hline \multicolumn{6}{|c|}{ Variables describing favourable areas for European rabbit damage } \\
\hline DRY_OLIV & 3 & 124.834 & + & + & \\
\hline HIGHW_RAILW & 1 & 119.444 & + & + & \\
\hline IRR_OLIV & 7 & 51.344 & + & + & \\
\hline DRY_VIN & 8 & 43.624 & + & + & \\
\hline IRR_VIN & 4 & 26.387 & + & + & \\
\hline F_WILDRABBIT & 11 & 15.961 & + & + & \\
\hline ORG_CER & 10 & 13.372 & + & + & \\
\hline WOLIV_COP & 9 & 9.238 & + & + & \\
\hline WOLIV_FOR & 13 & 7.006 & + & + & \\
\hline P_UAA & 14 & 4.157 & + & + & \\
\hline NOAK_CLEFOR & 6 & 9.686 & + & - & SW \\
\hline \multicolumn{6}{|c|}{ Variables describing unfavourable areas for European rabbit damage } \\
\hline DEV_OAK & 5 & 32.730 & - & - & \\
\hline PAST & 12 & 7.016 & - & - & \\
\hline DIV_FOR & 2 & 6.276 & - & - & \\
\hline PINE_FOR & 17 & 5.619 & - & - & \\
\hline GALL_FOR & 16 & 5.294 & - & - & \\
\hline OAK_CLEFOR & 18 & 4.075 & - & - & \\
\hline PAST_SHRUB & 15 & 9.360 & - & + & $\mathrm{SE}, \mathrm{E}, \mathrm{NE}$ \\
\hline \multicolumn{6}{|c|}{$\begin{array}{l}\text { Step, order of entrance in the model; W, univariate Wald test statistic quantifying variable significance in the model (all the variables shown were } \\
\text { significant at } P<0.05) \text {; CfS, sign of the variable coefficient in the model; CrS, sign of the correlation (Spearman) between the variable and favourability } \\
\text { values; AGl, area of geographical influence of the variable in the model within the study area (SW, southwest; NE, northeast; E, east; SE, southeast). } \\
\text { DRY_OLIV, dry olive groves ( } \% \text { area); HIGHW_RAILW, length of highway and high-speed railway per municipality (m); IRR_OLIV, irrigated olive groves (\% } \\
\text { area); DRY_VIN, dry vineyards (\% area); IRR_VIN, irrigated vineyards (\% area); F_WILDRABBIT, favourability model for the presence of European rabbits, } \\
\text { based on climate, topography and human activity (Table S1); ORG_CER, organic cereal (\% area); WOLIV_COP, beech forest (\% area); WOLIV_FOR, wild } \\
\text { olive tree forest (\% area); P_UAA, proportion of useful agricultural area (\% area); NOAK_CLEFOR, carob forest (\% area); DEV_OAK, development phase } \\
\text { of oaks (height); PAST, pastures ( } \% \text { area); DIV_FOR, diversity of forest uses and vegetation structure (Simpson diversity index); PINE_FOR, birch forest } \\
\text { (\% area); GALL_FOR, alignment (\% area); OAK_CLEFOR, boxwood forest (\% area); PAST_SHRUB, pastures and shrubs (\% area). }\end{array}$} \\
\hline
\end{tabular}

vegetation and land use factors. The sum of the pure and shared effects of these factors on favourability variation was $81.8 \%$ and $53.7 \%$, respectively (Fig. 5). Transport infrastructure and environmental favourability for the presence of European rabbits only explained $8.4 \%$ and $10.6 \%$ of variation, respectively. We found shared effects between the different factors (meaning either cross or indistinguishable explanatory power). Land uses and infrastructure shared $90.3 \%$ of their influence, and land use and natural vegetation shared $40.8 \%$. The other shared effects between factors were considerably smaller. As a result, the pure effect of natural vegetation explained $39 \%$ of favourability for the presence of damage, whilst the pure effect of land uses, environmental favourability for the presence of European rabbits, and infrastructure explained only $10.0 \%, 3.0 \%$ and $2.3 \%$, respectively.

\section{DISCUSSION}

We show that rabbit damage is more common in the central-southern regions of Spain, and in some northern areas (Fig. 2). We also demonstrate that the likelihood of damage by rabbits in an area depends on a combination of factors, which our model has clearly identified (Fig. 5). Most rabbit damage occurs in municipalities where farming dominates (and therefore natural vegetation is scarce), where main railways and highways are present and where environmental conditions for rabbit populations to succeed are generally good (Table S2). Using our approach, we were able to highlight those areas potentially at greater risk of rabbit damage at a large national scale, which are likely to be missed using other means of verification. For example, our model clearly showed that areas such as the Castilla y León region (northwestern Spain) have relatively high favourability values even though the number of cases found in our Google search was low (Figs 2 and 3).

Our study demonstrates that the modelling approach we use can be useful in determining the role of multiple factors at large spatial scales in explaining the damage caused by a pest species. In addition, we show that use of online media reports on pest damage can be an effective and relatively rapid option to understand the distribution of pest damage in a landscape as large as an entire country. However, a potential drawback of this information is that reports in the media on pest damage may only record the stakeholders' perceptions, but perceived and actual damage caused by wildlife may not be correlated. ${ }^{33}$ Despite this, media reports have been successfully used previously to assess the impact of small mammal pests. ${ }^{34}$ Thus, we argue that, even if there is some error involved, the information obtained in our study can help identify areas of potential stakeholder conflict regarding the management of pest species (farmers and hunters in our study model), ${ }^{18,24}$ and can be used in the design of more realistic management plans.

According to the analysed websites in Spain, most rabbit damage occurred in crops. This is in line with the result of our model in which favourable areas for rabbit damage were positively correlated with several land uses related to agriculture; many different crop types were among the most important predictors of rabbit damage (Table 1). Our results suggest that, in Spain, the rabbit is a generalist agricultural pest as a variety of crops are damaged 


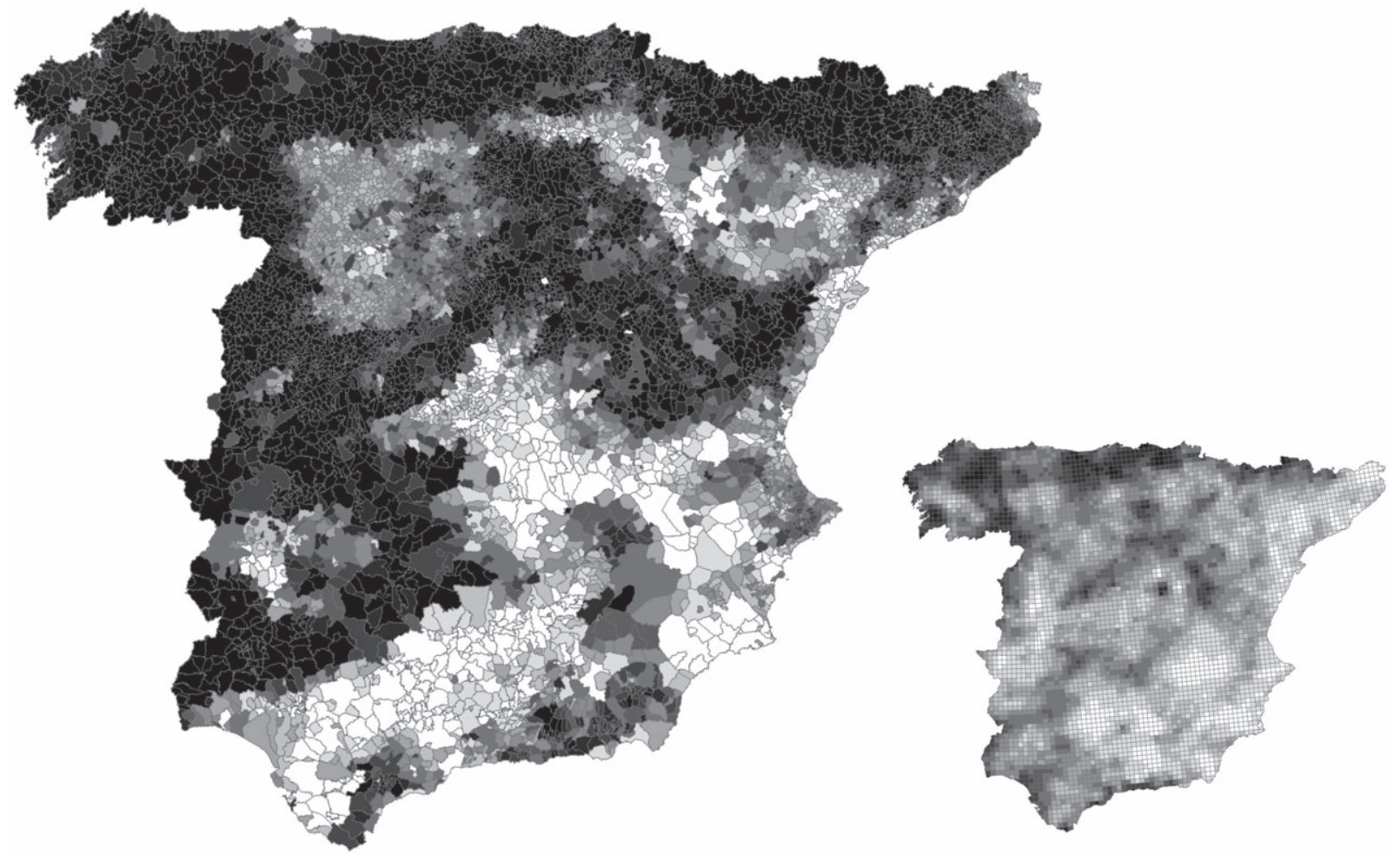

Figure 3. Favourability model for European rabbit damage in each municipality of mainland Spain. The small map shows the environmental favourability for the presence of European rabbit in Spain, on UTM $10 \times 10 \mathrm{~km}$ squares. The scale ranges from 0 (black) to 1 (white).

by this species (see also Ríos-Saldaña et $a l^{20}$ ). This contrasts with other Spanish small mammal pests that are linked to specific crop types; e.g. voles and herbaceous crops. ${ }^{35}$ Using the analysed websites, we showed that vineyards were the most frequently recorded crop type affected by rabbits, and both these and olive groves had significant effects on rabbit damage favourability in the model (Table 1). Notable reductions in woody crop yields from rabbit browsing have been reported in some Spanish agricultural regions. ${ }^{21}$ Given that a vast proportion of agricultural land in some regions of Spain is devoted to these woody crops - e.g. $>98 \%$ of the area in the Montilla-Moriles wine-growing region in southern Spain $^{36}$ - losses caused by rabbits to olive oil and wine producers can be economically crippling.

Natural vegetation explained a large proportion of favourability for rabbit damage in our model (Table 1). The fact that most natural vegetation types were negatively associated with the potential occurrence of rabbit damage is not surprising, because the higher the proportion of land occupied by natural vegetation, the lower the availability of crops to be grazed by rabbits. Furthermore, rabbits are found in low numbers in areas dominated by forests or dense scrublands, ${ }^{37}$ thus decreasing the likelihood of damage to adjacent crops. Similarly, we observed that rabbit damage is most likely in areas environmentally favourable for the species (Table 1). In these areas, high rabbit densities are possible in addition to being positively associated with the presence of woody crops, ${ }^{38}$ typically damaged by rabbits.

Although the number of hunters in Spain has remained relatively constant (http://www.magrama.gob.es), rabbits hunted have increased alongside the spread of high-speed railways during the last decade (Fig. $1 ; R=0.904 ; P<0.001$ ). According to our model, one of the main predictors of rabbit damage was the presence of railways or motorways (Table 1; Fig. 4). The explanation is that rabbits can become more abundant close to these infrastructures, ${ }^{39,40}$ particularly in areas within farmland regions where the availability of other suitable habitat for their successful establishment is low. ${ }^{41}$ Verges and embankments along roads or railways (for high-speed railways these are often chain-mesh security fenced) provide rabbits with refuge against predators and hunters, as predator abundance is lower and hunting often banned in these areas. ${ }^{39,41}$ In addition, these verges and embankments offer ideal conditions for rabbit warren building, ${ }^{40}$ essential to establish healthy social groups. ${ }^{42,43}$ Similar reasons have been proposed to explain the high numbers of some small mammals found in areas with high road density ${ }^{44}$ or the intensive use of areas adjacent to roads by juveniles of two lagomorph species. ${ }^{45}$ In farmland areas, rabbits usually establish dense populations along the verges of roads and railway lines, where nearby crops are their only feeding source as natural vegetation has almost disappeared as a consequence of intensive agricultural practices. ${ }^{36}$ This may also explain the high importance of human infrastructure in explaining rabbit damage observed in the model.

Our Google searches uncovered very few sites containing information related to rabbit pests in Spain during the first half of the 2000s. This was a time when Spanish rabbit populations were at their lowest numbers in recorded history because most of them had not recovered from the huge impact of rabbit haemorrhagic disease (RHD), first detected in Spain in $1988 .{ }^{46}$ The increase in the number of websites reporting damage between 2006 and 2012 matches the known recovery of some populations during that period, ${ }^{47,48}$ particularly in some agricultural areas. ${ }^{18}$ It also matches the increase in the number of rabbit control requests and the number of harvested rabbits recorded in Portugal ${ }^{18}$ and in Spain (Fig. 1). These findings closely resemble the situation in 


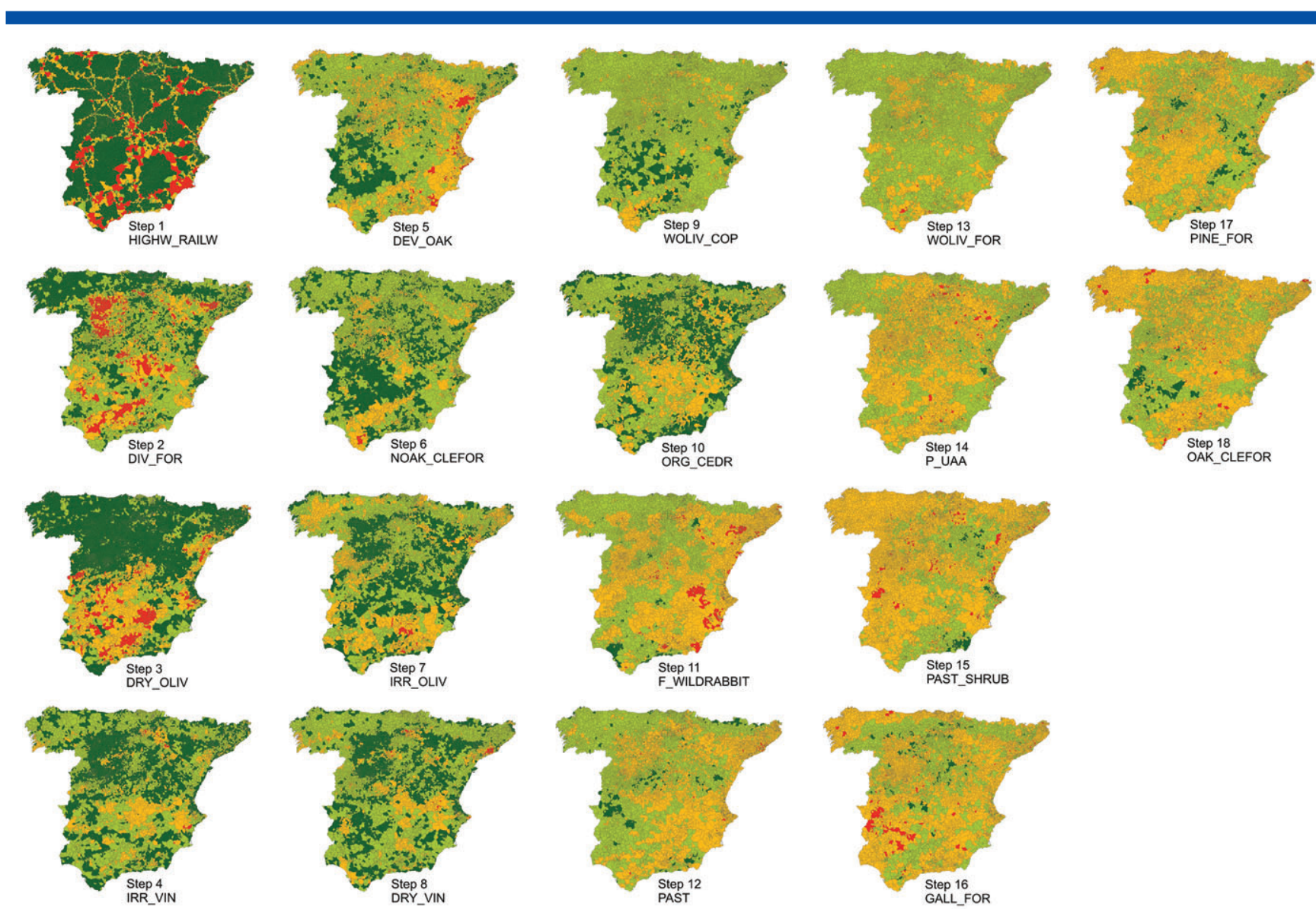

Figure 4. Mapped contribution of variables to the model of favourability for European rabbit damage along the stepwise variable selection. Step, order of entrance in the model; green, negative contribution to damage; red, positive contribution to damage; HIGHW_RAILW, length of highway and high-speed railway per municipality (m); DIV_FOR, diversity of forest uses and vegetation structure (Simpson diversity index); DRY_OLIV, dry olive groves (\% area); IRR_VIN, irrigated vineyards (\% area); DEV_OAK, development phase of oaks (height); NOAK_CLEFOR, carob forest (\% area); IRR_OLIV, irrigated olive groves (\% area); DRY_VIN, dry vineyards (\% area); WOLIV_COP, beech forest (\% area); ORG_CER, organic cereal (\% area); F_WILDRABBIT, favourability model for the presence of European rabbits, based on climate, topography and human activity (Table S1); PAST, pastures (\% area); WOLIV_FOR, wild olive tree forest (\% area); P_UAA, proportion of useful agricultural area (\% area); PAST_SHRUB, pastures and shrubs (\% area); GALL_FOR, alignment (\% area); PINE_FOR, birch forest (\% area); OAK_CLEFOR, boxwood forest (\% area).

Australia, where rabbit numbers were heavily suppressed by RHD between 1995 and 2002, but increased 5-10-fold between 2003 and $2010 . .^{49}$ Our findings also show that in 2013 the available online information related to rabbit damage fell sharply, which seems to be only explicable by the population crash caused by a new variant of the RHD virus. ${ }^{48,50,51}$ It is very likely that the decline in rabbits observed in agricultural areas resulted in reduced rabbit damage, which was reflected in the lower number of websites addressing this issue. Interestingly, the number of websites reporting rabbit damage increased considerably between 2013 and 2014 (Fig. 1), which suggests that rabbit populations might have recovered at least in some agricultural areas, although in natural areas rabbit numbers were still very low. ${ }^{51}$

Our findings indicate that the evolution of online reports on rabbit damage might be a good indicator of trends in the rabbit population and rabbit damage at a large scale in Spain, although such data have some potential limitations. For example, the relationship between rabbit abundance and damage is complex, as damage to crops by rabbits has been also observed in areas with moderate rabbit abundance. ${ }^{18}$ Also, the considerable increase in the use of the internet over recent years might explain the growing availability of online information regarding almost any topic. However, the observed rise in rabbit damage reports when we controlled for sampling effort per year and the growing numbers of rabbits hunted and rabbit control permits requested ${ }^{18,20}$ suggest that rabbit damage has in fact increased in recent years in Spain. In any case, we do recommend that online data be interpreted cautiously. The presence of transport infrastructure was one of the main explanatory factors of rabbit damage in our model. Given the extensive development of high-speed railways and highways that has occurred in Spain in recent years, we suggest that such landscape modification may have been one of the main drivers in the rise in rabbit damage reported in our study. This seems to be supported by the significant overlap observed between the increase in the number of websites dealing with rabbit pests and the increase in the length of high-speed railways in Spain (Fig. $1 ; R=0.869 ; P<0.001$ ). An alternative explanation is that the reduction of other food sources for rabbits has led to increased crop damage. ${ }^{36}$ The role of humans in the expansion of small mammal pests and damage by these pests has been also observed in other farmland systems. ${ }^{35}$

Economic damage caused by mammal pest species can be high, particularly in farmland areas (e.g. Pimentel et al..$^{52}$ ). This may be a source of conflict between stakeholders whose livelihood is affected by wildlife, such as farmers, and other parties that make 


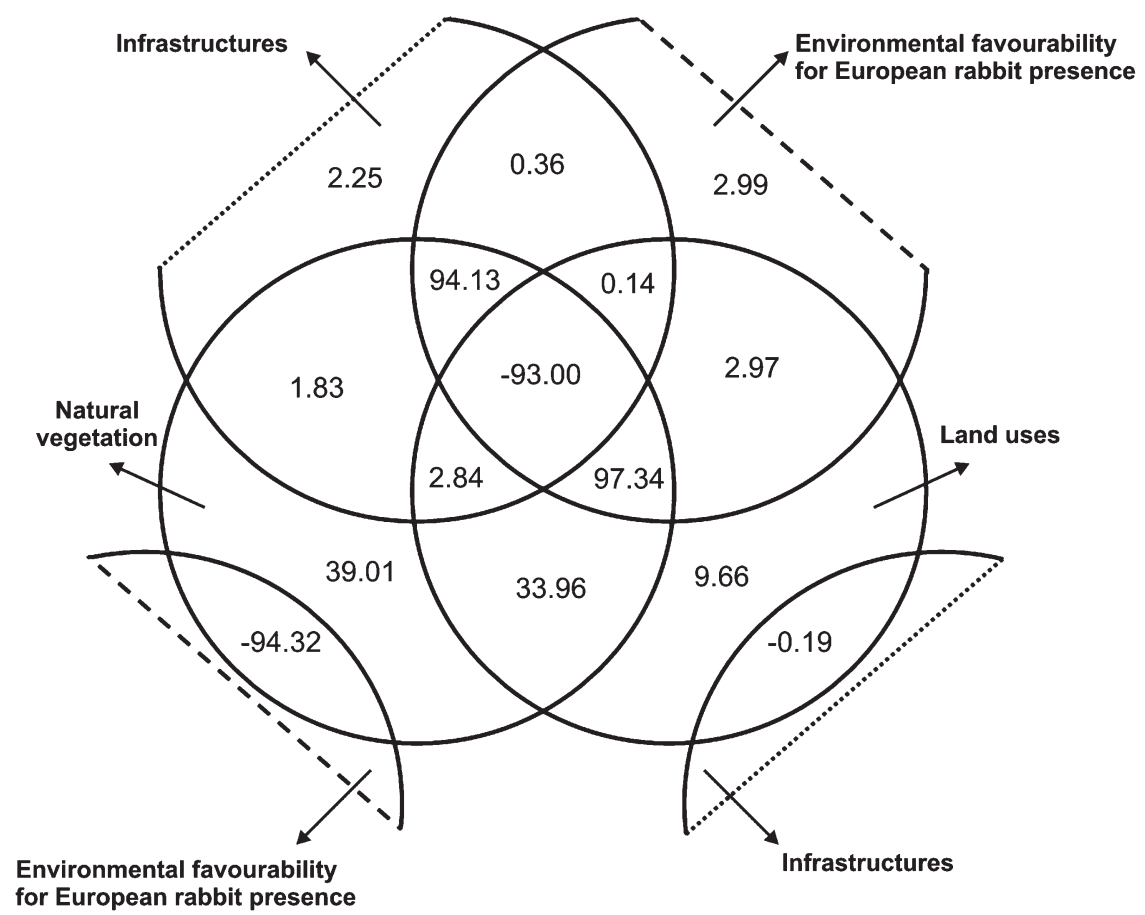

Figure 5. Variation partitioning of the final model. Values show the proportions of how much of the variation in environmental favourability for European rabbit damage occurrence is explained exclusively by infrastructure, environmental favourability for European rabbit presence, natural vegetation and land use factors, and which proportion was attributable to their shared effects (intersections).

other uses of these species, such as hunters or environmentalists. Our case study is a good example, but there are others across the world. ${ }^{16,53}$ We suggest that it is essential to assess what drives wildlife damage at large spatial scales as well as to identify areas where potential conflicts may emerge. The approach presented in this paper can be reproduced in other systems, not only to reduce wildlife pest damage, but also to work towards reducing tension between stakeholders regarding the management of wildlife.

\section{ACKNOWLEDGEMENTS}

We wish to thank three anonymous reviewers for constructive comments. M. Delibes-Mateos and C. Rouco were supported by the Talentia Postdoc and Talent Hub Program, respectively, launched by the Andalusian Knowledge Agency, and co-funded by the European Union's Seventh Framework Program, Marie Skłodowska-Curie actions (COFUND - Grant Agreements n267226 and 291780, respectively) and the Ministry of Economy, Innovation, Science and Employment of the Junta de Andalucía. M. Delibes-Mateos is currently funded by V Plan Propio de Investigación of the Universidad de Sevilla. This study is a contribution of the projects CGL2013-43197-R (I + D National Plan), funded by the Spanish Ministry of Science and Innovation and EU-FEDER funds, and 1098/2014 (Organismo Autónomo Parques Nacionales, Spain).

\section{SUPPORTING INFORMATION}

Supporting information may be found in the online version of this article.

\section{REFERENCES}

1 Woodroffe R, Thirgood S, Rabinowitz A, People and Wildlife, Conflict or Co-existence? Cambridge University Press, Cambridge, United Kingdom (2005).
2 Conover MR, Resolving human-wildlife conflicts: The science of wildlife damage management. CRC Press, Boca Raton, United States (2002).

3 Capizzi D, Bertolino S and Mortelliti A, Rating the rats: global pattern and research priorities in impacts and management of rodent pests. Mammal Review 44:148-162 (2014).

4 Imholt C, Reil D, Plasil P, Rödinger K and Jacob J, Long-term population patterns of rodents and associated damage in German forestry. Pest Management Science 73:332-340. (2017).

5 Mutze G, Cooke B and Jennings S, Density-dependent grazing impacts of introduced European rabbits and sympatric kangaroos on Australian native pastures. Biological Invasions 18:2365-2376 (2016).

6 Mills S, Rabbits breed a growing controversy. New Scientist 109:50-54 (1986).

7 Gong W, Sinden J, Braysher M and Jones R, The economic impacts of vertebrate pests in Australia. Invasive Animals Cooperative Research Centre, Canberra, Australia (2009).

8 White PCL and Harris S, Economic and environmental costs of alien vertebrate species in Britain. In Biological invasions: economic and environmental costs of alien plant. Animal and microbe species, ed. by Pimentel D, CRC Press, Boca Raton, USA, pp. 113-149 (2002).

9 Cooke B, Chudleigh P, Simpson S and Saunders G, The economic benefits of the biological control of rabbits in Australia, 1950-2011. Australian Economic History Review 53:91 - 107 (2013).

10 Panzacchi M, Bertolino S, Cocchi R and Genovesi P, Population control of coypu Myocastor coypus in Italy compared to eradication in UK: a cost-benefit analysis. Wildlife Biology 13:159-171 (2007).

11 Watve M, Patel K, Bayani A and Patil P, A theoretical model of community operated compensation scheme for crop damage by wild herbivores. Global Ecology and Conservation 5:70-80 (2016).

12 Shepherd RF, Bennett DD, Dale JW, Tunnock S, Dolph RE and Thier RW, Evidence of synchronized cycles in outbreak patterns of Douglas-fir tussock moth, Orygia pseudotsugata (McDunnough) (Lepidoptera: Lymantriidae). Memoirs of the Entomological Society of Canada 106:107-121 (1988)

13 Ruiz GM and Carlton JT, Invasive species: Vectors and management strategies. Island Press, Washington, USA (2003).

14 Wallner AM, Hamilton GC, Nielsen AL, Hahn N, Green EJ and Rodriguez-Saona CR, Landscape factors facilitating the invasive dynamics and distribution of the brown marmorated stink bug, Halyomorpha halys (Hemiptera: Pentatomidae), after arrival in the United States. PLOS One 9:e95691 (2014). 
15 Bellamy PE, Shore RF, Ardeshir D, Treweek JK and Sparks TH, Road verges as habitat for small mammals in Britain. Mammal Review 30:131-139 (2000).

16 Delibes-Mateos M, Smith AT, Slobodchikoff C and Swenson J, The paradox of keystone species persecuted as pests: a call for the conservation of abundant small mammals in their native range. Biological Conservation 144:1335-1346 (2011).

17 Delibes-Mateos M, Delibes M, Ferreras P and Villafuerte R, Key role of European rabbits in the conservation of the western Mediterranean basin hotspot. Conservation Biology 22:1106-1117 (2008).

18 Delibes-Mateos M, Ferreira C, Rouco C, Villafuerte R and Barrio IC, Conservationists, hunters and farmers: The European rabbit Oryctolagus cuniculus management conflict in the Iberian Peninsula. Mammal Review 44:190-203 (2014).

19 Barrio IC, Bueno CG and Tortosa FS, Alternative food and rabbit damage in vineyards of southern Spain. Agriculture, Ecosystems, and Environment 138:51-54 (2010).

20 Ríos-Saldaña CA, Delibes-Mateos M, Castro F, Martínez E, Vargas JM, Cooke BD and Villafuerte R, Control of the European rabbit in central Spain. European Journal of Wildlife Research 59:573-580 (2013).

21 Real R, Barbosa AM, Rodriguez A, García FJ, Vargas J, Palomo LP and Delibes $\mathrm{M}$, Conservation biogeography of ecologically interacting species: the case of the Iberian lynx and the European rabbit. Diversity and Distributions 15:390-400 (2009).

22 Font I, Climatología de España y Portugal. Ediciones Universidad de Salamanca, Salamanca, Spain (2000).

23 MAGRAMA, Encuesta sobre superficies y rendimientos de cultivos: resultados nacionales y autonómicos. Ministerio de Agricultura, Alimentación y Medio Ambiente, Madrid, Spain (2015).

24 Delibes-Mateos $M$, Rumours about wildlife pest introductions: European rabbits in Spain. Ambio 46:237-249 (2017)

25 Avila, M, El conejo y sus daños: caracterización especial. MSc Thesis, Universidad de Castilla-La Mancha, Ciudad Real, Spain (2010).

26 Real R, Barbosa AM and Vargas JM, Obtaining environmental favourability functions from logistic regression. Environmental and Ecological Statistics 13:237-245 (2006).

27 Acevedo P and Real R, Favourability: concept, distinctive characteristics and potential usefulness. Naturwissenschaften 99:515-522 (2012).

28 Palomo LJ, Gisbert J, Blanco JC, Atlas y Libro Rojo de los Mamíferos Terrestres de España. Dirección General para la BiodiversidadSECEM-SECEMU, Madrid, Spain (2007).

29 Benjamini $Y$ and Hochberg Y, Controlling the false discovery rate: a practical and powerful approach to multiple testing. Journal of the Royal Statistical Society: Series B 57:289-300 (1995).

30 Legendre P and Legendre L, Numerical ecology. Second edition. Elsevier Science, Amsterdam, The Netherlands (1988).

31 Hosmer DW and Lemeshow S, Applied logistic regression. WileyInterscience, New Jersey, USA (2000).

32 Barbosa AM, Real R and Vargas JM, Transferability of environmental favourability models in geographic space: the case of the Iberian desman (Galemys pyrenaicus) in Portugal and Spain. Ecological Modelling 220:747-754 (2009).

33 Nyierinda VR, Myburgh WJ, Reilly BK, Phiri Al, Chabwela HN, Wildlife crop damage valuation and conservation: conflicting perception by local farmers in the Luangwa Valley, eastern Zambia. International Journal of Biodiversity and Conservation 5:741-750 (2013).

34 Luque-Larena JJ, Mougeot F, Viñuela J, Jareño D, Arroyo L, Lambin X and Arroyo $B$, Recent large-scale range expansion and outbreaks of the common vole (Microtus arvalis) in NW Spain. Basic and Applied Ecology 14:432-441 (2013).
35 Jareño D, Viñuela J, Luque-Larena JJ, Arroyo B and Mougeot F, Factors associated with the colonization of agricultural areas by common voles Microtus arvalis in NW Spain. Biological Invasions 17:2315-2327 (2015)

36 Barrio IC, Bueno CG, Villafuerte R and Tortosa FS, Rabbits, weeds and crops: can agricultural intensification promote wildlife conflicts in semiarid agro-ecosystems? Journal of Arid Environments 90:1-4 (2013).

37 Lombardi L, Fernández N, Moreno S and Villafuerte R, Habitat-related differences in rabbit (Oryctolagus cuniculus) abundance, distribution and activity. Journal of Mammalogy 84:26-36 (2003).

38 Delibes-Mateos M, Farfán MA, Olivero J and Vargas JM, Land-use changes as a critical factor for long-term wild rabbit conservation in the Iberian Peninsula. Environmental Conservation 37:169-176 (2010).

39 Bautista LM, García JT, Calmaestra RG, Palacín C, Martín CA, Morales MB, Bonal $R$ and Viñuela J, Effect of weekend road traffic on the use of space by raptors. Conservation Biology 18:726-732 (2004).

40 Barrientos $\mathrm{R}$ and Bolonio $\mathrm{L}$, The presence of rabbits adjacent to roads increases polecat road mortality. Biodiversity and Conservation 18:405-418 (2009).

41 Planillo A and Malo JE, Motorway verges: Paradise for prey species? A case study with the European rabbit. Mammalian Biology 78:187-192 (2013).

42 Cowan D, Aspects of the Social Organisation of the European wild rabbit (Oryctolagus cuniculus). Ethology 75:197-210 (1987).

43 Cowan D, Group Living in the European Rabbit (Oryctolagus cuniculus): Mutual Benefit or Resource Localization? Journal of Animal Ecology 56:779-795 (1987).

44 Rytwinski T and Fahrig L, Effect of road density on abundance of white-footed mice. Landscape Ecology 22:1501-1512 (2007).

45 Bissonette JA and Rosa SA, Road zone effects in small-mammal communities. Ecology and Society 14:27 (2009).

46 Delibes-Mateos M, Ferreras P and Villafuerte R, European rabbit population trends and associated factors: a review of the situation in the Iberian Peninsula. Mammal Review 39:124-140 (2009).

47 Garrido JL, La Caza. Sector Económico. Valoración por subsectores. FEDENCA-EEC, Madrid, Spain (2012). http://www.oficinanacional decaza.org/descargas/318/ (accessed 10 July 2016)

48 Delibes-Mateos M, Ferreira C, Carro F, Escudero MA and Gortázar $C$, Ecosystem effects of variant hemorrhagic disease virus, Iberian Peninsula. Emerging Infectious Diseases 20:2166-2168 (2014).

49 Mutze G, Bird P, Jennings S, Peacock D, de Preu N, Kovaliski J, Cooke $B$ and Capucci L, Recovery of South Australian rabbit populations from the impact of rabbit haemorrhagic disease. Wildlife Research 41:552-559 (2015).

50 Guerrero-Casado J, Carpio AJ and Tortosa FS, Recent negative trends of wild rabbit populations in southern Spain after the arrival of the new variant of the rabbit hemorrhagic disease virus RHDV2. Mammalian Biology 81:361-364 (2016).

51 Monterroso P, Garrote G, Serronha A, Santos E, Delibes-Mateos M, Abrantes J, Pérez de Ayala R, Silvestre F, Carvalho J, Vasco I, Lopes A, Maio E, Magalhães M, Mills SL, Esteves P, Simón MA and Alves PC, Disease-mediated bottom-up regulation: An emergent virus affects a keystone prey, and alters the dynamics of trophic webs. Scientific Reports 6:36072 (2016).

52 Pimentel D, Lach L, Zuniga R and Morrison D, Environmental and Economic Costs of Nonindigenous Species in the United States. BioScience 50:53-65 (2000).

53 Linkie M, Dinata $Y$, Nofrianto A and Leader-Williams N, Patterns and perceptions of wildlife crop raiding in and around Kerinci Seblat National Park, Sumatra. Animal Conservation 10:127-135 (2007). 